\title{
Photochemical Rearrangement of a 6-Azasteroid Oxaziridine to a Novel 17 $\beta$-Carbomethoxy-A-homo-B-seco-6-aza-3, 5-androstanedione
}

\author{
Stephen Frye*1 \\ Department of Medicinal Chemistry, Glaxo Inc. Research Institute, Five Moore Drive, Research Triangle Park, North Carolina
}

Received June 23, 2009; accepted August 31, 2009

\begin{abstract}
. 4- and 6-azasteroids have been shown to be potent inhibitors of human $5 \alpha$-reductase and certain azasteroids have shown significant clinical benefit in the treatment of androgen-related disorders. In an effort to expand the diversity of steroidal heterocycles synthetically accessible for structure-activity relationship exploration, a novel reaction sequence was applied to the preparation of the 6-azasteroid framework. To this end, photolysis of the oxaziridine derived from $17 \beta$-carbomethoxy- $3 \beta$-triisopropylsilyloxy-6-azaandrost-5-ene (1) yielded a novel 7, 5-steroidal ring system that was evaluated for inhibition of human type 1 and $25 \alpha$-reductase.

Key words: Azasteroids, 5a-reductase, steroidal heterocycles, photochemistry, synthesis, oxaziridine
\end{abstract}

\section{Introduction}

The 4- and 6-azasteroid skeletons have yielded extremely potent inhibitors of both isozymes of human $5 \alpha$-reductase (5AR) [1]. The activity of these inhibitors has been rationalized based on the ability of the amide and vinylogous amide functionality to bind strongly to the active site residues which have evolved to stabilize the enolate-like transition state through which the reduction of testosterone to dihydrotestosterone proceeds [2]. Other molecular analogies to the enolate, or enol-like, transition state may be envisaged $[3,4]$, and the possibility of properly positioning a stabilized enol in the 5AR active site was of interest to me. As is often the case, both the genesis and realization of this design concept depended upon prior work aimed at developing synthetic methodology $[5,6]$.

With 6-azasteroids readily available in multi-gram quantities as a result of our 5AR drug discovery program, the synthetic work of Aubé et al. [5] inspired the design of novel Ahomo-B-seco-6-azasteroids as potential transition state mimics of the conversion of testosterone to dihydrotestosterone as depicted in Figure 1. This paper describes the synthesis of the novel A-homo-B-seco-6-azasteroid framework and its activity as an inhibitor of human type 1 and $25 \mathrm{AR}$.

${ }^{1}$ Current contact information: UNC Eshelman School of Pharmacy, Division of Medicinal Chemistry and the Center for Integrative Chemical Biology and Drug Discovery, 120 Mason Farm Road, Campus Box 7363, University of North Carolina, Chapel Hill, NC 27599-7363; e-mail: svfrye@email.unc.edu; phone: 9198435486.
Resumen. Los 4- y 6-azaesteroides mostraron ser potentes inhibidores de la $5 \alpha$-reductasa humana, y otros azaesteroides fueron eficientes en el tratamiento clínico de desórdenes relacionados a los andrógenos. En un esfuerzo para ampliar la diversidad de heterociclos esteroidales que se obtengan sintéticamente, con el fin de explorar sus relaciones de estructura-actividad, se empleó una novedosa secuencia de reacciones para la preparación de 6-azaesteroides. De esta forma, la fotólisis de la oxaziridina derivada del $17 \beta$-carbometoxi-3 $\beta$-triisopropilsililoxi-6-azaandrost-5-eno (1) proporcionó un nuevo sistema esteroidal de anillos fusionados de 5 y 7 miembros, el cual se evaluó en la inhibición de la $5 \alpha$-reductasa humana de tipos 1 y 2 .

Palabras clave: Azaesteroides; 5a-reductasa; heterociclos esteroidales; fotoquímica,; síntesis; oxaziridina.

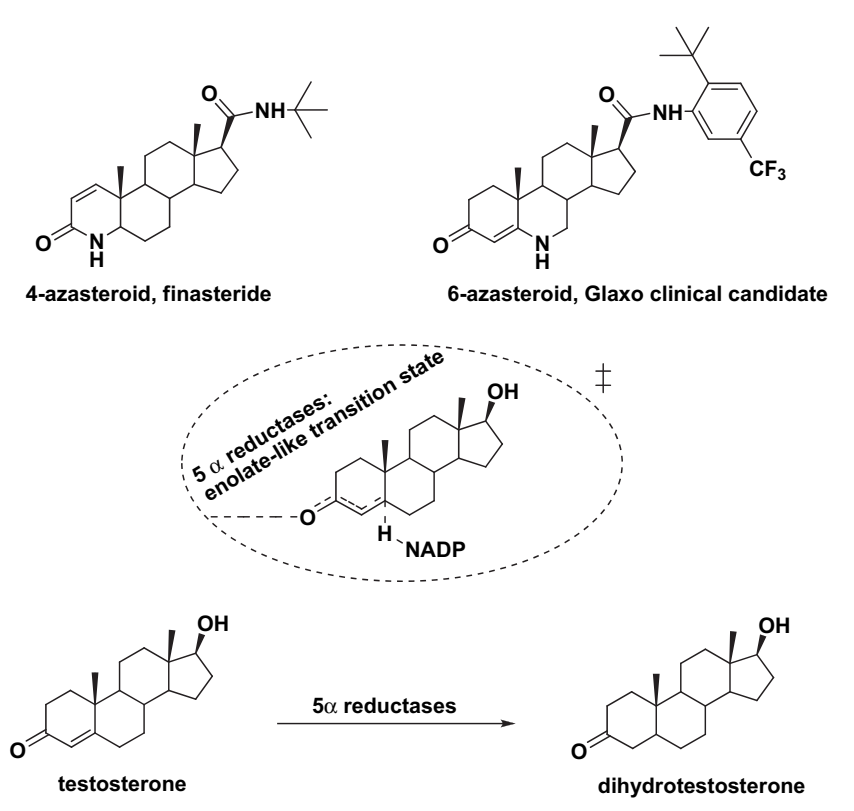

Fig. 1. 4 and 6-azasteroid 5 $\alpha$-reductase inhibitors and depiction of the enzymatic conversion of testosterone to dihydrotestosterone via an enolate-like transition state.

\section{Results and Discussion}

Oxaziridines have been prepared from imines and shown to rearrange regioselectively to amides under photolysis conditions $[5,6]$. Application of this methodology to the imine intermediate utilized in the synthesis of 6-azasteroids (Figure 2, compound 1 , available in $65 \%$ yield from $3 \beta$-hydroxyetienic acid methyl ester as previously described) [2b], would allow 
access to a $\beta$-ketoamide (5 and 7) in the A-ring of the steroid which could present a stabilized enol for interaction with the active site of 5AR. The simultaneous expansion of the A-ring and contraction of the B-ring of the steroid would also allow a reasonable geometric overlap with both the steroid skeleton and the 3-keto function of previously known potent inhibitors. To this end, imine 1 was treated with $m$-chloroperoxybenzoic acid in toluene at $-78{ }^{\circ} \mathrm{C}$ to give, after extractive workup, oxaziridine 2 as a single isomer in $70 \%$ yield of sufficient purity to carry forward. Photolysis of a $0.035 \mathrm{M}$ solution of 2 in methylene chloride for $15 \mathrm{~min}$ followed by flash chromatographic purification provided an $82 \%$ yield of rearranged adduct 3 which was deprotected with tetrabutylammonium fluoride to give 4 in $62 \%$ yield. Oxidation of 4 with Jones reagent gave $\beta$-ketoamide 5 in $16 \%$ yield. Unfortunately neither $\mathbf{4}$ nor $\mathbf{5}$ demonstrated inhibition of either isozyme of human $5 \mathrm{AR}$ at $2.0 \mathrm{mg} / \mathrm{mL}$. Compounds 6 and 7 with a $\mathrm{C} 17$ isobutyl ketone substituent (which previous SAR suggests would be more potent than the $\mathrm{C} 17$ methyl ester [2b]) were prepared in similar fashion from the $\mathrm{C} 17$ isobutyl ketone substituted imine corresponding to $\mathbf{1}$ and neither showed significant activity.

Though unsuccessful in so far as inhibition of 5AR is concerned, the preparation of 4-7 represents an important extension of oxaziridine photochemistry over previous exocyclic oxaziridines $[5,6]$, which results in the conversion of a 6,6-bicyclic imine to a novel 7,5-bicyclic lactam containing steroid.
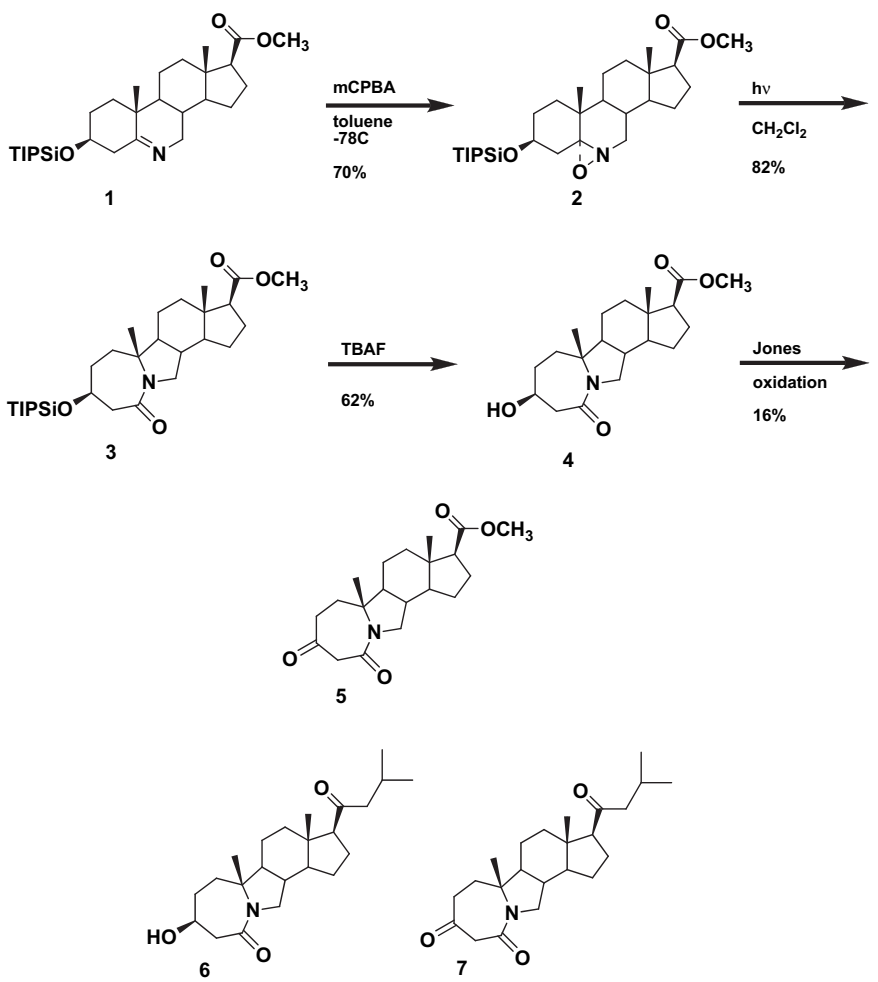

Fig. 2. Synthetic scheme for preparation of compounds 4-7.

\section{Experimental}

6-Aza-[5,6- $\alpha$-oxo]-3 $\beta$-hydroxyetienic acid methyl ester (2). A solution of $12 \mathrm{~g}(24.5 \mathrm{mmol})$ compound 1 in $180 \mathrm{~mL}$ toluene was added dropwise over 40 minutes to a rapidly stirred suspension of $12.7 \mathrm{~g}(50 \% \mathrm{mCPBA}, 1.5 \mathrm{eq})$ in $150 \mathrm{~mL}$ toluene at $-78{ }^{\circ} \mathrm{C}$. After $20 \mathrm{~min}$. no starting material remained by TLC ( $20 \%$ ethyl acetate/hexanes, p-anisaldehyde visualization), saturated sodium dithionite $(100 \mathrm{~mL})$ was added, diethyl ether added $(300 \mathrm{~mL})$, the organics washed with bicarbonate, saturated sodium chloride, dried over $\mathrm{MgSO}_{4}$ and concentrated. Flash chromatography (20-50\% ethyl acetate/hexanes) gave $8.65 \mathrm{~g}(70 \%)$ compound 2 as a light yellow solid free from residual mCPBA and pure by ${ }^{1} \mathrm{H} \mathrm{NMR}\left(300 \mathrm{MHz}, \mathrm{CDCl}_{3}\right)$.

17 $\beta$-Carbomethoxy-A-homo-B-seco-6-aza-3 $\beta$-hydroxy-5androstanone (4). A solution of $1.05 \mathrm{~g}(20.7 \mathrm{mmol})$ compound 2 in $600 \mathrm{~mL} \mathrm{CH} \mathrm{Cl}_{2}$ was degassed by passing dry $\mathrm{N}_{2}$ through the solution for $20 \mathrm{~min}$ and was then photolyzed (quartz filter) for $30 \mathrm{~min}$ at which point TLC analysis (20\% ethyl acetate/ hexanes, $\mathrm{p}$-anisaldehyde visualization) showed no remaining starting material. Treatment with activated charcoal followed by flitration through a silica gel plug and flash chromatography (20-30\% ethyl acetate/hexanes) gave $0.86 \mathrm{~g} \mathrm{(82 \% )}$ compound 3. Standard deprotection of $0.78 \mathrm{~g}(15.4 \mathrm{mmol})$ of 3 with $1 \mathrm{M}$ tetra-butyl ammonium fluoride in THF followed by extractive work-up and flash chromatography $(50 \%$ ethyl acetate/hexanes with gradual addition of $5 \%$ methanol/ $\mathrm{CH}_{2} \mathrm{Cl}_{2}$ ) gave 364 mg (62\%) compound 4: Anal. Calcd for $\mathrm{C}_{20} \mathrm{H}_{31} \mathrm{NO}_{4}$ : C, 68.74; H, 8.94; N, 4.01. Found: C, 68.86; H, 8.98; N, 4.02; ${ }^{1} \mathrm{H}$ NMR $\left(300 \mathrm{MHz}, \mathrm{CDCl}_{3}\right)$ - see supplementary material.

17 $\beta$-Carbomethoxy-A-homo-B-seco-6-aza-3,5-androstanedione (5). Treatment of 4 (77 mg, $0.22 \mathrm{mmol})$ dissolved in 20 $\mathrm{mL}$ acetone in an ice bath with freshly prepared Jones reagent (drop wise until orange color persists) followed by addition of isopropanol, concentration, extractive work-up (dissolution in ethyl acetate, washing with saturated bicarbonate and sodium chloride solutions), concentration and crystallization from ethyl acetate/hexanes gave $12.2 \mathrm{mg}(16 \%)$ compound 5: High resolution mass spectra $\mathrm{m} / \mathrm{z}=348.2174$, Calcd for $\mathrm{C}_{20} \mathrm{H}_{30} \mathrm{NO}_{4}$ $=348.2175 .{ }^{13} \mathrm{C}$ NMR $\left(100 \mathrm{MHz}, \mathrm{CDCl}_{3}\right): \delta 202.9,174.0$, 163.7, 63.3, 57.3, 54.3, 54.2, 53.3, 53.0, 51.4, 51.1, 45.3, 38.9, $37.5,36.2,34.8,24.3,23.9,20.8,20.6,13.9 ;{ }^{1} \mathrm{H}$ NMR (300 $\mathrm{MHz}, \mathrm{CDCl}_{3}$ ) - see supplementary material.

Compounds 6 and 7 were prepared in a similar fashion from the $\mathrm{C} 17$ isobutyl ketone corresponding to compound $\mathbf{1}$; ${ }^{1} \mathrm{H}$ NMR (300 MHz, $\mathrm{CDCl}_{3}$ ) - see supplementary material for NMR spectra of intermediates and final compounds.

\section{Acknowledgments}

This paper is dedicated to the memory of Professor Ernest Eliel - a gentleman and scholar who gave so much to chemistry and the world. 


\section{References}

1. Russell, D. W.; Wilson, J. D. Annu. Rev. Biochem. 1994, 63, 2561

2. (a) Rasmusson, G. H.; Reynolds, G. F.; Steinberg, N. G.; Walton, E.; Patel, G.F.; Liang, T.; Cascieri, M. A.; Cheung, A. H.; Brooks, J. R.; Berman, C. J. Med. Chem. 1986, 29, 2298-2315. (b) Frye, S. V.; Haffner, C. D.; Maloney, P. R.; Mook, R. A.; Jr., Dorsey, G. F.; Jr., Hiner, R. N.; Cribbs, C. M.; Wheeler, T. N.; Ray, J. A.; Andrews, R. C.; Batchelor, K. W.; Bramson, H. N.; Stuart, J. D.; Schweiker, S. L.; Van Arnold, J.; Croom, S.; Bickett, D. M.; Moss, M. L.; Tian, G.; Unwalla, R. J.; Lee, F. W.; Tippin, T. K.; James, M. K.; Long, J. E.; Schuster, S. V. J. Med. Chem. 1994, 37, 2352-2360. (c) Frye, S. V. Current Pharm. Design 1996, 2, 59-84.
3. Pirrung, M. C.; Chen, J.; Rowley, E. G.; McPhail, A. T. J. Am. Chem. Soc. 1993, 115, 7103-7110.

4. (a) Holt, D. A.; Levy, M. A.; Oh, H.-J.; Erb, J. M.; Heaslip, J. I.; Brandt, M.; Lan-Hargest, H.-Y.; Metcalf, B. W. J. Med. Chem. 1990, 33, 943-950. (b) Haffner, C.D. Tetrahedron Lett. 1994, 35, $1349-1353$.

5. Lattes, A.; Oliveros, E.; Riviere, M.; Belzecki, C.; Mostowicz, D.; Abramskj, W.; Piccinni-Leopardi, C.; Germain, G.; Meerssche, M. V. J. Am. Chem. Soc. 1982, 104, 3929-3934.

6. (a) Aubé, J.; Wang, Y.; Hammond, M.; Tanol, M.; Takusagawa, F.; Velde, D. V. J. Am. Chem. Soc. 1990, 112, 4879-4891. (b) Aubé, J. Chem. Soc. Rev. 1997, 26, 269-277. 